\title{
PENGOLAHAN SAMPAH TERPADU DESA KARANGKATES UNTUK MENCAPAI ZERO WASTE
}

\author{
Anis Artiyani 1), Dwi Ana Anggorowati ${ }^{2)}$ \\ 1)Teknik Lingkungan, Institut Teknologi Nasional Malang \\ 2) Teknik Kimia, Institut Teknologi Nasional Malang \\ Email: anisartiyani@ymail.com
}

\begin{abstract}
Abstrak. Desa Karangkates berupaya untuk menyelesaikan permasalahan sampah dimana volume sampah sangat berdampak pada lingkungan disekitarnya, maka dari itu direncanakan pengelolaan sampah dengan sistem 3 R yaitu : Reduce (Mengurangi), Reuse (Menggunakan Kembali), dan Recycle (Mendaur Ulang). Penyediakan sarana dan prasarana kebersihan. Pengolahan Sampah Terpadu di Desa Karangkates untuk mencapai Zero Waste bisa dilaksanakan. Data komposisi dapat diketahui jenis sampah yang paling banyak yaitu sampah basah atau sisa makanan dan daun sebesar 54,48 \% dimana sampah basah tersebut akan di buat pengomposan. Tersedianya semua fasilitas yang dibutuhkan dalam proses pengelolaan sampah termasuk pengadaan peralatan, sarana dan prasarana yang bisa digunakan oleh penduduk untuk memilah milah sampah sejak berada di TPST. Dari hasil pengolahan data bahwa kelompok ibu rumah tangga lebih banyak mendominasi kegiatan pengolahan sampah, terutama pengolahan sampah organik yang kemudian menjadi kompos. Di Desa Karangkates organisasi yang berasal dari masyarakat seperti PKK membina bagaimana memanfaatkan sampah dan mengembangkan pola pikir masyarakat tentang pentingnya pengolahan sampah sebagai peningkatan ekonomi dengan pendirian bank sampah.
\end{abstract}

Kata Kunci: Kompos,Pengolahan Terpadu, Sampah, Zero Waste

\section{PENDAHULUAN}

Desa Karangkates merupakan salah satu desa yang terdapat di Kecamatan Sumberpucung Kabupaten Malang, dengan jumlah penduduk sebanyak 10.864 jiwa, terdiri dari 5.485 jiwa penduduk laki-laki dan 5.579 jiwa penduduk perempuan. Luas wilayah Desa Karangates adalah 564,20 Ha. Luas wilayah dan jumlah penduduk yang besar dapat mempengaruhi sistem persampahan di desa tersebut.

Meningkatnya taraf hidup dan aktifitas manusia menimbulkan resiko menurunnya kualitas lingkungan. Salah satu faktor terpenting yang dapat mempengaruhi penurunan kualitas lingkungan adalah volume timbulan sampah yang selalu meningkat.Jumlah atau volume sampah sebanding dengan tingkat konsumsi terhadap barang / material yang digunakan sehari hari. Permasalahan mengenai sampah harus ditangani secara tepat dan tidak hanya mengenai masalah pengolahannya saja tetapi juga meliputi upaya pengelolaan. Indri Primasari dkk (2010) menjelaskan bahwa pengelolaan sampah berbasis $3 \mathrm{R}$ meliputi pemilahan, pengomposan, daur ulang dengan total timbulan sampah pada Kecamatan Ngaliyan sebesar 349,27 m3/hari dapat direduksi menjadi $132,3 \mathrm{~m} 3 / \mathrm{hr}$. Zero Waste adalah pengelolaan sampah yang di mulai dari produksi sampai berakhirnya suatu proses produksi

Adanya permasalahan maka penelitian ini berupaya membantu Pengolahan Sampah Terpadu di Desa Karangkates untuk Mencapai Zero Waste, sehingga perlu dilakukan pengelolaan sampah secara serius. Permasalahan sektor persampahan di Desa Karangkates yaitu:

1. Timbulan sampah yang semakin banyak dengan kurang optimalnya pengelolaan di Tempat Pengolahan Sampah Terpadu.

2. Pengadaan peralatan, sarana dan prasarana yang bisa digunakan oleh penduduk dalam membantu pengolahan sampah, agar sampah dapat dipilahpilah sejak berada di TPST. 
3. Pola pikir masyarakat tentang pentingnya pengolahan sampah sebagai peningkatan ekonomi yang perlu disosialisasikan lagi melalui pelatihan/pembinaan.

Tujuan dari penelitian ini adalah Pengolahan Sampah Terpadu di Desa Karangkates untuk Mencapai Zero Waste, dengan upaya-upaya sebagai berikut :

1. Mengoptimalkan pengelolaan di Tempat Pengolahan Sampah Terpadu dengan mengurangi timbulan sampah.

2. Pendataan pengadaan peralatan, sarana dan prasarana yang bisa digunakan oleh penduduk dalam membantu pengolahan sampah, agar sampah dapat dipilahpilah sejak berada di TPST.

3. Mengembangkan pola pikir masyarakat tentang pentingnya pengolahan sampah sebagai peningkatan ekonomi.

\section{METODE PENELITIAN}

Lokasi tempat penelitian di Desa Karangkates yang memiliki jumlah peduduk di tahun 2017 sebesar 10.864 jiwa. Desa Karangkates mempunyai jarak dengan permukiman sekitar $+500 \mathrm{~m}$.dimana TPST sebagai lokasi pengolahan sampah.

\section{Tahapan Analisis Data}

\section{Teknik Pengambilan Sampel}

Guna menentukan timbulan sampah yang dihasilkan dari suatu permukiman perlu dilakukan survey pengambilan contoh sampah langsung di sumber sampah. Adanya permasalahan di Desa Karangkates seperti besarnya timbulan sampah, kurangnya sarana prasarana pengolahan sampah dan pola pikir masyarakat yang belum memahami adanya nilai ekonomi dari sampah maka dalam penelitian ini akan mebantu bagaimana cara Pengolahan Sampah Terpadu di Desa Karangkates untuk mencapai Zero Waste. Karena itu dalam pengolahan sampah yang dilakukan ada 2 sistem pengolahan yaitu:

1. Pengolahan sampah basah - Komposting Merupakan pengolahan sampah basah secara biologis melalui proses penguraian yang berlangsung dalam kondisi aerobic.

2. Pengolahan sampah kering Misalnya melalui proses pembakaran/ insenerasi dan upaya daur ulang sampah yang ditampung oleh Bank Sampah.

\section{Metodologi Pelaksanaan \\ Pengolahan sampah ditunjukan untuk mengurangi volume sampah dan/atau mengurangi daya cemar sampah. Proses pengolahan sampah yang dilakukan di Desa Karangkates diklasifikasikan menjadi 2 yaitu proses pengolahan sampah secara fisik dan biologi.}

Proses pengolahan secara biologis yang dilakukan di Desa Karangkates yaitu Proses aerobik merupakan proses oksidasi parsial untuk mereduksi volume dan daya cemar sampah dengan bantuan mikroorganisme aerobik dalam kondisi keberadaan oksigen (udara).

\section{HASIL PENELITIAN}

\section{Jumlah Penduduk}

Jumlah penduduk Desa Karangkates dalam lima (5) tahun terakhir dapat di lihat pada tabel 1:

Tabel 1. Jumlah dan Pertumbuhan Penduduk Desa Karangkates 5 tahun terakhir

\begin{tabular}{|c|c|c|c|}
\hline TAHUN & $\begin{array}{c}\text { JMLH } \\
\text { PENDUDUK }\end{array}$ & $\begin{array}{c}\text { PERTUMBU } \\
\text { HAN } \\
\text { PENDUDUK }\end{array}$ & $\begin{array}{c}\% \\
\text { PERTUMBUH } \\
\text { AN }\end{array}$ \\
\hline 2013 & 8.679 & 0 & 0 \\
\hline 2014 & 10.969 & 2.290 & 26 \\
\hline 2015 & 10.969 & 0 & 0 \\
\hline 2016 & 10.977 & 8 & 0.073 \\
\hline 2017 & 10.864 & -113 & -1.02 \\
\hline Total & 52.458 & 2.185 & 25.053 \\
\hline
\end{tabular}

\section{Kondisi Pengelolaan Persampahan Di Desa}

\section{Karangkates}

Penanganan masalah persampah di Kabupaten Malang, khususnya di Kecamatan Sumberpucung, Desa Karangkates saat ini ditangani oleh sebuah instansi pemerintah yaitu oleh Dinas Lingkungan Hidup Kabupaten Malang dengan di bantu oleh pihak Swasta dan bantuan masyarakat setempat. Permasalahan sampah di Desa Karangkates belum dikelola secara tepat 
Proses pemilahan sampah dilakukan oleh warga pada setiap hari sangat mengurangi jumlah sampah yang dibuang di TPA. Sistem pengumpulan sampah ini dilakukan di Desa Karangkates pada pagi atau sore hari.

Kesadaran masyarakat dalam membuang sampah tidak pada tempatnya, banyak warga yang membuang sampah pada tanah kosong atau tanah pinggir jalan ladang dan pekarangan seperti yang terlihat pada Gambar 1 berikut ini:
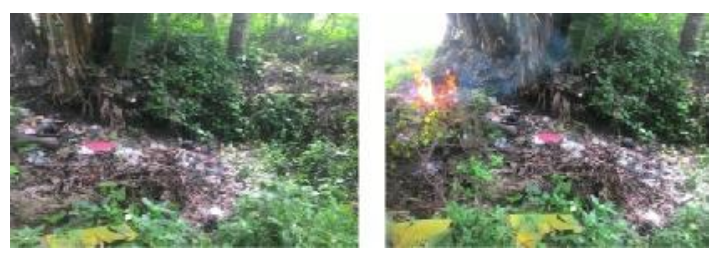

Gambar 1. Cara Pembuangan Sampah Warga

Pemindahan sampah di Desa Karangkates masih menggunakan gerobak motor sehingga tidak terjadinya pemindahan sampah namun langsung di bawa ke TPA. Pengangkutan sampah menggunakan kendaraan roda 3 dengan kapasitas bak $3 \mathrm{~m}^{3}$ yang akan mengangkut sampah-sampah dari rumah-rumah penduduk dan langsung dibawa menuju TPA.

\section{Teknik Operasional Pengelolaan Sampah Di Desa Karangkates}

Teknik operasional pengelolaan sampah di kawasan permukiman meliputi proses sebagai berikut :

\section{Timbulan dan Volume Sampah di Desa} Karangkates

- Pengukuran dan pengambilan contoh timbulan dan komposisi sampah

- Mengumpulkan sampah rumah tangga

- Langkah-langkah yang dilakukan pada saat penelitian dimulai dari mengelompokkan jenis rumah berdasarkan klasifikasi rumah yang terdiri dari rumah permanen, semi permanen dan non permanen,

- Pembagian kantong plastik.

- Penimbangan berat sampah sesuai klasifikasi rumah
- Sampah dikategorikan sesuai jenisnya untuk mengetahui komposisi sampah

Timbulan sampah pada penelitian ini dihitung berdasarkan jumlah sampel dan jumlah sampah yang dihasilkan oleh masyarakat Desa Karangkates.

2. Komposisi, Berat, Volume Sampah Komposisi berdasarkan jenis sampah terlihat pada Tabel 2.

Tabel 2. Prosentase Komposisi berdasarkan Jenis Sampah yang ada di Desa Karangkates

\begin{tabular}{|l|c|c|}
\hline No & Jenis sampah & $\begin{array}{c}\text { Rata-rata } \\
(\%)\end{array}$ \\
\hline 1 & $\begin{array}{c}\text { Sisa } \\
\text { makanan+daun }\end{array}$ & 54,48 \\
\hline 2 & Kertas & 12,73 \\
\hline 3 & Kain & 0,98 \\
\hline 4 & Kayu & 1,45 \\
\hline 5 & Kaca & 0,75 \\
\hline 6 & Plastik & 19,73 \\
\hline 7 & Diapers & 12,33 \\
\hline 8 & Karet & 0,12 \\
\hline 9 & Streofoam & 0,37 \\
\hline 10 & B3 & 0,20 \\
\hline 11 & Kaleng & 1,31 \\
\hline 12 & Kawat & 0,17 \\
\hline 13 & Kabel & 0,36 \\
\hline & Total & $\mathbf{1 0 4 , 8 9}$ \\
\hline
\end{tabular}

Hasil data komposisi sampah tersebut, dapat diketahui jenis sampah yang paling banyak yaitu sampah basah atau sisa makanan dan daun sebesar 54,48 \% dimana sampah basah tersebut akan di buat pengomposan. Selain itu juga dapat diketahui material balance sampah yaitu mengalikan komposisi sampah dengan faktor pemilahan pada material daur ulang (\%). Material balance digunakan untuk menentukan persentase sampah residu dan sampah daur ulang. Faktor pemilahan (\%) dan material balance sampah dapat dilihat pada tabel 3 . 
Tabel 3. Faktor Pemilahan (\%) dan material balance sampah.

\begin{tabular}{|l|l|l|l|}
\hline Perlakuan & $\begin{array}{l}\text { Jenis } \\
\text { Sampah }\end{array}$ & $\begin{array}{l}\text { Rata2 } \\
\text { Komposisi } \\
\text { Sampah }\end{array}$ & $\begin{array}{l}\text { Reco } \\
\text { vary } \\
\text { Facto } \\
\text { r }\end{array}$ \\
\hline \multirow{4}{*}{ Residu } & Kain & 0,98 & 0 \\
\cline { 2 - 4 } & Kayu & 1,45 & 0 \\
\cline { 2 - 4 } & Diapers & 12,33 & 0 \\
\cline { 2 - 4 } & Karet & 0,12 & 0 \\
\cline { 2 - 4 } & Dll & 1,85 & 0 \\
\hline & Jumlah & $\mathbf{1 6 , 7 3}$ & \\
\hline \multirow{3}{*}{ Dipilah } & Kertas & 12,73 & 100 \\
\cline { 2 - 4 } & Plastik & 19,73 & 100 \\
\cline { 2 - 4 } & Karet & 1,31 & 63 \\
\hline & Jumlah & $\mathbf{3 3 , 7 7}$ & \\
\hline \multirow{2}{*}{$\begin{array}{l}\text { Residu } \\
\text { Dari } \\
\text { Pemilaha } \\
\mathrm{n}\end{array}$} & Kertas & 0 & 100 \\
\cline { 2 - 4 } & Plastik & 0 & 100 \\
\cline { 2 - 4 } & Kaleng & 0,48 & 37 \\
\hline & Jumlah & $\mathbf{0 , 4 8}$ & \\
\hline
\end{tabular}

\section{Hasil Perhitungan}

Hasil data material balance sampah, dapat diketahui persentase sampah yang dapat di daur ulang adalah $33,77 \%$. Sedangkan total sampah residu merupakan sampah residu ditambah dengan sampah residu dari pemilahan.Sehingga total sampah residu sebesar $17,21 \%$.

Sistem pewadahan pada Desa Karangkates masih tercampur antara sampah basah dan sampah kering. Setelah dilakukan penelitiani ini upaya pewadahan yang digunakan di Desa Karangkates untuk warga mulai dipisahkan antara sampah basah dan kering.

\section{Sistem Pengelolaan Sampah}

Di Desa Karangkates dalam pengelolaan sampah setelah dilakukan pembinaan sudah dilakukan dari rumah mereka. Proses ini membedakan sampah berdasarkan jenis-jenis sampah antara lain organik (sampah dapur yang berupa sayur-sayuran, buah, dan lain lain), nonorganik (kertas, plastik, dan lain-lain)

Sistem pengumpulannya dengan cara sampah yang telah terpilah atau dibedakan sudah sesuai dengan jenisnya (anorganik dan B3) dan dibungkus dalam kantong plastik, diletakkan warga di halaman rumah atau tong sampah umum yang telah tersedia, tong sampah umum yang disediakan terdiri dari 2 warna, yaitu warna kuning untuk menampung sampah kering seperti plastik, kaleng dan warna hijau untuk sampah organik. Terlihat pada gambar 2 berikut:

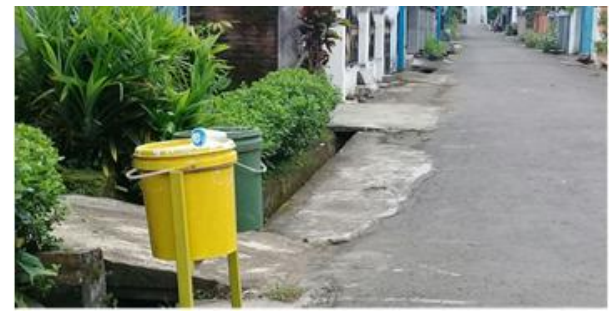

Gambar 2. Wadah yang di gunakan kuning sampah kering dan hijau sampah basah

Proses pengangkutan sampah, yang paling sesuai dengan cara tidak langsung karena pada pengangkutan sampah di Desa Karangkates hanya dilakukan oleh petugas pengangkut sampah dengan jumlah 3 orang. Kegiatan pengangkutan tersebut dilakukan pada setiap hari. Sampah yang telah diangkut petugas dan dibawa ke tempat pembuangan sampah sementara. Alat yang dipergunakan dalam pengangkutan sampah yaitu gerobak sampah.

Pengolahan sampah di Desa Karangkates, sampah didaur ulang secara manual, yaitu dengan menggunakan ember atau tong bekas yang digunakan untuk memproses sampah organik (sampah dapur yang berupa sayur sayuran, buah, dll) untuk dijadikan kompos ini sebagai upaya zero waste seperti terlihat pada Gambar -3 berikut ini:

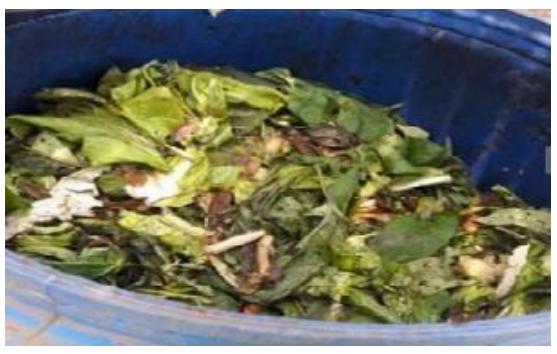

Gambar 3.Proses Pengomposan sampah organik

Selain itu masyarakat sekarang juga mendaur ulang sampah organik, kertas, dan plastik bekas, guna meningkatkan nilai ekonomi dan lahan pekerjaan. Dari hasil pengolahan data bahwa kelompok ibu rumah tangga lebih banyak mendominasi kegiatan pengolahan sampah, terutama pengolahan sampah organik 
yang kemudian menjadi kompos. Sedangkan kelompok lain tidak banyak yang melakukan kegiatan pengolahan tersebut dikarenakan lebih banyak beraktivitas di luar wilayah tempat tinggal.

Akan tetapi kegiatan pendaur ulangan sampah berbahan dasar kertas masih lebih didominasi oleh kelompok responden lain seperti pemulung, mengingat bahwa kegiatan tersebut tidak selalu dilakukan setiap hari seperti pada pembuatan kompos. Peran serta masyarakat dalam pengelolaan sampah di Desa Karangkates cukup besar, namun masih terdapat masyarakat yang belum melakukan kegiatan tersebut. Dalam kegiatan pengolahan sampah ini warga juga mendapatkan keuntungan dibidang estetika dan keindahan lingkungan, kompos dimanfaatan sendiri sebagai pupuk tanaman di rumah warga. Hasil proses komposting dapat dilihat pada Gambar 4 berikut ini:

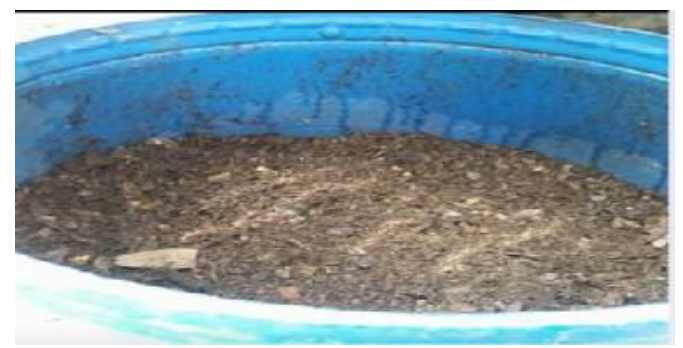

Gambar 4. Proses Komposting

Analisis peran serta masyarakat dalam pembiayaan pada kegiatan pengelolaan sampah diperlukan biaya untuk mempermudah jalannya kegiatan tersebut, karena dengan demikian akan memaksimalkan semua yang diperlukan oleh masyarakat setempat, upaya yang dilakukan merangkul mitra seperti perum jasa tirta dan PLTA harapannya adanya mitra tersebut akan membantu pendanaan guna tersedianya semua fasilitas yang dibutuhkan dalam proses pengelolaan sampah yang terlihat pada. Famplet dan slogan himbauan bersih lingkungan dipasang di titik tertentu yang disinyalir tempat warga membuang sampah secara liar seperti terlihat pada gambar-5 berikut ini:

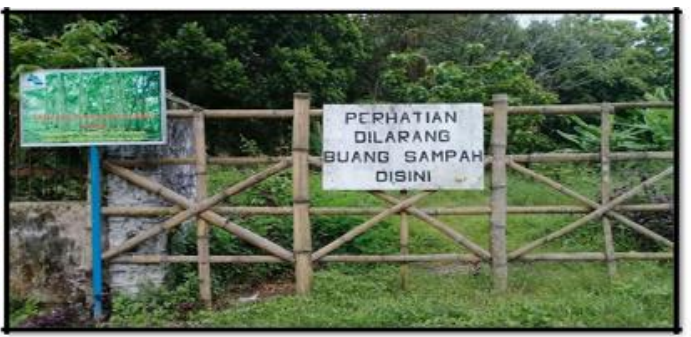

Gambar 5 Slogan atau Baner Larangan membuang Sampah Kerjasama dengan Mitra Perum Jasa Tirta

Pada sistem pembiayaan pribadi dalam kegiatan pengelolaan sampah, warga Desa Karangkates cukup mengeluarkan biaya untuk para petugas pengangkut sampah saja, dan untuk biaya yang dikeluarkan warga akan disesuaikan dengan jumlah sampah yang dikeluarkan.Biaya hanya tergantung dari jumlah sampah yang dikeluarkan warga saja. Dengan jumlah biaya yang umum dikeluarkan oleh sebagian besar warga setempat yaitu sebesar Rp. 15.000,- tiap bulan dan jika pertahun Rp. 150.000. Kegiatan pengomposan warga mengeluarkan biaya sendiri dalam kelompok kelompok kecil warga yang mungkin memiliki lahan relatif cukup memadai untuk pengomposan

Analisis keterlibatan organisasi baik yang berasal dari instansi pemerintah terkait atau yang berasal dari masyarakat amat diperlukan, dimana kehadiran organisasi tersebut akan lebih mempermudah masyarakat dalam memperoleh informasi. Organisasi yang terkait dengan suatu kegiatan, khususnya yang melibatkan masyarakat, diharapkan dapat memberikan masukan yang baik bagi masyarakat, sekaligus sebagai wadah masyarakat untuk mengutarakan aspirasinya, maka fungsi organisasi dalam masyarakat dapat memberikan hasil yang baik, dalam penerapan maupun pelaksanaannya.

Di Desa Karangkates organisasi yang berasal dari masyarakat seperti PKK mengajari bagaimana memanfaatkan sampah dan pemanfaatan melalui bank sampah secara kecil karena keberadaan bank sampah pembayaran penjualan sampah diberikan 1 tahun sekali. Kegiatan penyuluhan bagi warga yang biasa diadakan setiap satu bulan sekali 


\section{KESIMPULAN}

Kesimpulan dari penelitian ini adalah :

1. Pengolahan Sampah Terpadu di Desa Karangkates untuk mencapai Zero Waste bisa dilaksanakan.

2. Data komposisi dapat diketahui jenis sampah yang paling banyak yaitu sampah basah atau sisa makanan dan daun sebesar $54,48 \%$ dimana sampah basah tersebut akan di buat pengomposan

3. Tersedianya semua fasilitas yang dibutuhkan dalam proses pengelolaan sampah termasuk pengadaan peralatan, sarana dan prasarana yang bisa digunakan oleh penduduk untuk memilah milah sampah sejak berada di TPST.

4. Dari hasil pengolahan data bahwa kelompok ibu rumah tangga lebih banyak mendominasi kegiatan pengolahan sampah, terutama pengolahan sampah organik yang kemudian menjadi kompos.

5. Di Desa Karangkates organisasi yang berasal dari masyarakat seperti PKK membina bagaimana memanfaatkan sampah dan mengembangkan pola pikir masyarakat tentang pentingnya pengolahan sampah sebagai peningkatan ekonomi dengan pendirian bank sampah

\section{SARAN}

Saran yang harus dilakukan antara lain :

1. Perlunya peran serta antara pihak Dinas Kebersihan, Aparat setempat dan masyarakat untuk saling bersinergi guna Pengolahan sampah yang zero waste.

2. Perlu adanya dukungan dana untuk penyesuaian semua fasilitas yang dibutuhkan dalam pengelolaan sampah terpadu

\section{DAFTAR PUSTAKA}

[1]. Damanhuri dan Padami. 2010. Pengelolaan Sampah: Departemen Teknik Lingkungan Fakultas Sipil Dan Perencanaan Institut Teknologi Bandung.

[2]. Indri Primasari. 2010. Jurnal tentang: Perencanaan Pengelolaan Sampah Terpadu Berbasis 3R Di Kecamatan Ngaliyan. Jurusan Teknik Lingkungan Fakultas Sipil Dan Perencanaan Universitas Diponegoro
[3]. Kementerian Pekerjaan Umum, 2014. Buku Pedoman 3R, Jakarta Selatan.

[4]. Kuncoro Sejati. 2008. Pengolahan Sampah Terpadu. Yogyakarta: Kanisius.

[5]. SNI 19-3964-1994 tentang Metode Pengambilan Dan Pengangkutan Semple Timbulan Dan Komposisi Sampah

[6]. SNI10-3983-1995 tentang Besaran Timbulan Sampah Berdasarkan Klasifikasi Kota.

[7]. SNI 19-2452-2002 tentang Tata Cara Teknik Operasional Sampah Perkotaan.

[8]. SNI 19-7030-2004 tentang Spesifikasi Kompos dari Sampah Organik Domestik.

[9]. SNI SNI-3242-2008 tentang Tata Cara Pengelolaan Sampah di Permukiman. 